\title{
Albanian Poetry after the ' 60 and Its Interrelations with Myth, History and Reality
}

\section{Edlira Dhima}

\author{
Ismail Qemal University of Vlora, College of Human Sciences \\ Department of Language and Literature, Vlora, Albania
} E-mail: edadhima@gmail.com

\section{Doi:10.5901/jesr.2013.v3n7p365}

\begin{abstract}
The modern Albanian poetry, likewise the traditional Albanian poetry has been greatly affected by social and historical factors. In a major part, it acknowledges the historical facts, thus reverberating and eternalizing them in verses. In different stages of social processes, the excessive engagement on the poet's behalf has made possible the fact that the language of poetry does not distinguishes from the political declarations. The frequent use of symbols that everyone is familiar with, has helped these poets to disengage from the straightforwardness of discourse. After the ' 60 , a group of poets converted the artistic linguistic text from a historical fact into a mythic symbol. These poets introduced the myth in poetry and the symbol as a communication language, created a coherent symbol system, an enclosed cycle and their own symbolic system, with which the interpretive community was more or less familiar. Among them, someone like Ismail Kadare was not satisfied only with the creation of a symbolic system within poetry, thus unfolded and developed this poetic symbolic system in prose and in the meantime granted it with the attribute of universal dimension. The familiarization with their symbolic language, which initially had a simpler level of communication (due to the unknown symbols could not be identified and analyzed thoroughly), makes it already a superior level communicative language. In the '70, makes its entry one other type of language, which is defined by a modest level of communication. As a language mainly expanded in Kosovo, it introduced an odd phenomenon and had unpredictable success.
\end{abstract}

\section{Introduction}

The history, reality and myth are found in a continuous severe war among them, which is identified as a war between declaration and insinuation as well as between the literary myth and the historical fact. Jung asserts that: "Myth is very individual and expresses life in a more holistic manner than science, which operates with concepts of average and is far from the expressiveness of individual's life varieties ${ }^{1 "}$

Inasmuch as the myth is a framework which raises questions and give answers by posing the same question through the pattern "This is like this, isn't it" and which concurrently is considered as a perpetual contradiction of mimicry ${ }^{2}$, the literature created from myth has induced in Albanian culture the imitative writing, thus overturning the kind of writing it creates.

For a long period of time, the Albanian literature should pay its dues, by transmuting it into an immense propagandistic authority of order and of the truism that characterizes it, in order to create a new independent one. Liberated from myth and transformed into a recorder of reality, of the crowd's motion and existing order, this type of literature has escaped far from its irrational and imaginative nature for a long time.

\section{Albanian literature and myths}

It is acknowledged, that the Albanian literature emanates with the book Meshari (Prayer Book), written by Gjon Buzuku, which indicates intelligibly that its beginning is closely related to the $16^{\text {th }}$ century, particularly somewhere amid of this century. As a documented and well-investigated element, we may introduce the main significant authors of this literature like Buzuku, Matrënga, Budi, Bardhi and Bogdani and many others. Viewed from this perspective, the relation of literature with myth and mythology, likewise legends and legendary, viewed and handled also as an unavoidable pre-text, is that of the ethno-religious myth, even by indicating its own myth, which is tangible and presented as a triple act:

- Evidence of the written Albanian language, already with books.

- Historical evidence of the development of lexicography and historiography.

${ }_{1}^{1}$ William Righter, Myth and literature, Routlege and Kegan Paul, London and Boston, 1975, pg 102.

2 William Righter, Myth and literature, Routlege and Kegan Paul, London and Boston, 1975, pg 97. 
- Literary evidence through the poetry and prose creation of P. Budi and P. Bogdani.

M. Barleti, who has written in Latin language works concerning humanity, has also established in the meantime a literary and historic myth, based upon the historical figure of Gjergj Kastriot Skënderbeu (George Kastrioti Scanderbeg). Scanderbeg's myth is more obviously unfolded during the era of National Renaissance, of the literature that aimed the national revival, meanwhile in the Arbëresh literature the myth of "glorious year" is essential and focuses its attention on the figure of Gjergj Kastriot Skënderbeu, a thing which is also encountered in some poetic works of Jeronim de Rada, Gavril Dara i Riu (Gavril Dara Junior), Zef Serembe, Zef Skiroi, and many others. On the other hand, the myth of our national hero, that of Gjergj Kastriot Skënderbeu, as a universal and spatial myth, meets a particular way of expressiveness even in the literary work of other poets of National Renaissance, like Naim Frashëri, Andon Zako Çajupi, Ndre Mjeda and others. However, the myth of Scanderbeg, being undoubtedly the most expanded in time and space, is still ongoing and present in contemporary literature, beginning with the novels of Ismail Kadare, Sabri Godo, Kasëm Trebeshina, until that of Ben Blushi, thus converting it into a prevalent myth that is embraced by the literary creative work of Albanian writers. On the other side, due to Lasgush, Migjeni, Konica the Albanian literature had the ability to create and present new expressive ways and perspectives, with regard to thematic and literary structure, as well as in conception and literary enunciation, which was unique and independent. In the first part of the $20^{\text {th }}$ century, there were many writers of Albanian literature, who re-functionalized the legend, tale and Albanian mythology; where the most predominant of this writing model are undoubtedly Mitrush Kuteli and Ernest Koliqi, the latter would write mainly on the basis of our mythology as well as of the Greek one. After the year 1945, the Albanian literature, based on the official model, followed the line of socialist realism. "The myth's exploitation in our literature, has been considered by the official aesthetic and criticism of the communist dictatorship era, as something not only redundant but also intolerable, as far as a socialist society is under the leadership of objective rules of development, that have been discovered by Marxism. Nevertheless, regardless of many ironic and derogatory attitudes toward myths, it never hindered some pens, to activate successfully in the contemporary literature myths and mythological subjects. ${ }^{3}$ "T.Caushi. Definitely here can be mentioned Ismail Kadare, where according to his concept, is undoubtedly one of the writers that has never hesitated to functionalize and represent in his literary works Albanian myths and legends, as well as myths and legends of other countries. Kadare, with the myth and legend, Albanian and foreign, in some occasions during the writing of long prose, always according to the scholar's viewpoint, mostly surpassed the borders of a segregated country of that time, thus transmitting universal messages, meanwhile beginning with well-known archetypes in the verbal creativity. Some of the well known myths were that of Scanderbeg and that of Arbër's resistance, precisely at the end of medieval era, as well as the myth of Albanian language (humanity religious literature). Meanwhile it was projected the myth of Our World and love, that led to the myth of glorious year, which prevalently reigned over the Arbëresh literature. To the same extent, was developed the myth of Western, which implied the detachment from the Ottoman Empire and the return in western European identity, the myth of survival and national resistance, or the myth of another Albania, a civilized contemporary literature and eligible to be compared to other developed European nations, as well as with the literary development itself. There is one other clear effort in the literature of socialist realism to create the myth of a new man, in the character's creation and conception, and this is a point worthy to discuss, but with regard to myth and mythology it was overthrown immediately after the falling of dictatorial system and that of the literary model of socialist realism. In this line stands also Sh. Sinani, who amid many things writes: "With one foot on the ancient Albania, the verbal and legendary one, still under the Homeric shuddering, and the other foot on the most prominent and cunning modernity, Kadare is found in the amid of these two distinct worlds, and from this extraordinary situation his work creates a powerful and eminent harmony ${ }^{4}$ ". These lines are extracted from a writing of Domenique Fernandez. To the same extent, the mythic and legendary opus of Camaj, which acquires a particular value in poetic texts, like Nema (Nemesis), Buelli (Buffalo), Palimpsest, but as a nature of writing it also occupies a considerable space in the prose and novels of the author. In the writing of poetry, the presence of myth is exposed clearly, as it occurs in the volume Legjenda (Legend), which expresses obviously the connections with myth as a legend, but in his poetic writing one may find also occasions of the myth's presence since at the title, but its presence becomes more substantial throughout the integrity of the text, likewise in Nema (Nemesis), Buelli (Buffalo) and Palimpsest, which in addition reveal the myth of poetry in the eternal pursuance, as well as the poet's myth, which is culminated with that of poetic text as a writing and overwriting process, alongside with myths of classical nature, like the buffalo. The signs of intertwining prose writing with other domains of mythic and legendary, reach their climax in the novels Karpa (The Crag), Rrathë (Circles) and mainly in his masterpiece, Dranja, which aside from others, reformulates the literary genre, a challenge and substantial literary experiment, like no one else

${ }^{3}$ T. Caushi, Fjalor i Estetikës, Ombra, GVG, Tiranë, 2005, pg. 297.

${ }^{4}$ Sh, Sinani, "Mitologji në Eposin e Kreshnikëve" , pg. 348 
in Albanian literature, where poetry and prose are merged. Its sources, of literary and powerful presence and revelation, of the intertwining and mergence of the literary aspect with the mythic, mainly accompanied by a legendary nature, are displayed in the poetic volume, not coincidentally entitled Legjenda (Legend), which indicates obviously the relations and connections with the mythic and legendary world, and in the meantime the beginning of modern poetry cultivation on the poet's behalf.

\section{Albanian poetry}

The Albanian poetry has been displaced from the chains of reality and the history's hostage by Lasgush Poradeci, who presumes the mass toward the primary voice, likewise Eliot asserts, the poets talks to himself or to no one ${ }^{5}$. This genre of poetry, with a straightforward language, became the poster of political reality which had taken it away from myth. This language thrived for almost 50 years in Albania.

Kosovo's poets escaped from reality and rarely praised the existing order, but this runaway in the history kept the poets' language as a hostage. The poetry of this period is empathized with allegory; meanwhile allegory itself is the reflecting image of language's associative indigence. The text was guided clearly via allegory toward a single point, and regardless of the undesignated phenomenon due to the censorship, the focus of figurativeness around allegory yields the same output: a unique message and language.

Between the poetry of declaration that confronts the reality and the poetry of declaration that confronts history, poets like Ali Podrimja, Azem Shkreli, Rhahman Dedaj and others, have accomplished transference of language in the domains of literary myth and individual symbol, thus converting the literary art into a multidimensional and polysemic nature.

Kadare's myth which is related to faith, to the sublime power of the given word, to the irrational and sub rational connections by placing next to each other the world and individuals, philosophy and faith is the sort of literary myth which has allowed the reality to become a symbol.

Camaj's poetry is related to myth, not to the traditional but to the individual one, which the poet himself created over the relics of traditional myth. His poetry is symbolic and symbols themselves are individuals, in many cases constructed upon collective mythic original patterns of Albanian tradition.

The Albanian literature was established in a cultural environment that produced huge advantages in the literary creativity that echoed the reality and history. This literary output is sometimes characterized by straightforwardness and other time is allegoric. As a consequence, the linguistic and artistic expressiveness has uniformity as well as it is codified and overloaded with encyclopedic signs.

The poetry of ' 70 , mainly expanded in Kosovo, represents an odd phenomenon of perceptiveness on the behalf of an interpretive community, who was not well prepared to communicate by means of such a language system. Kosovo's audience has perceived as patriotic poetry even those poetries that actually did not have that aim.

In parallel to this genre of poetry, is in ongoing process the poetry of a broader communication, written by Ndoc Gjtja, Ndoc Papleka, Xhevahir Spahiu, Agim Vinca and Moikom Zeqo.

Myths and symbols, that are an essential part of their language, are also the perpetual sustenance nowadays of the modern poetry around the world. The late Albanian poetry is a poetry that builds the new myth upon the old myth's relics.

\section{References}

Agim Vinca, Fije të pakëputura, Pro kultura, Shkup, 2004.

Azem Shkreli, Pagëzimi i fjalës, Rilindja, Prishtinë, 1981.

Basri Capriqi, Simboli dhe rivalët e tij, PEN- Qendra e Kosovës, 2005.

Ismail Kadare, Buzëqeshje mbi botë, Rilindja, 1980.

Martin Camaj, Jo gjithë jeta qenka burim poezie, Lirika, Dukagjini, Pejë, 2000.

Rexhep Qosja, Nocione të reja albanalogjike, IAP, Prishtinë, 1983.

Rrahman Dedaj, Gjëra që s'preken, Rilindja, Prishtinë, 1980.

Shaban Sinani, "Mitologji në eposin e kreshnikëve",TOENA, Tiranë, 2004.

Tefik Caushi, Fjalor i estetikës, Ombra, GVG, Tiranë, 2005.

Umberto Eko, Struktura e papranishme, Dukagjini, Pejë, 1994.

Umberto Eko, Autori dhe interpretuesit e tij, Jeta e re, nr. 5, Prishtinë, 2002.

William Righter, Mythand literature, Routlege and Kegan Paul, London and Boston, 1975.

${ }^{5}$ William Righter, Myth and literature, Routlege and Kegan Paul, London and Boston, 1975, pg. 68. 